\title{
Evaluasi Program Musyawarah Guru Mata Pelajaran Fisika SMA di Kabupaten Pangkep
}

\author{
Kaharuddin Arafah*1, Muamar Qadar ${ }^{2}$, Triyanto Pristiwaluyo ${ }^{2}$ \\ ${ }^{1}$ Jurusan Fisika, Universitas Negeri Makassar \\ ${ }^{2}$ Program Magister Penelitian dan Evaluasi Pendidikan, Universitas Negeri Makassar \\ *Email: kahar.arafah@unm.ac.id
}

Received: 24 April 2020;

Accepted: 7 Mei 2020;

Published: 16 Mei 2020

DOI: http://dx.doi.org/10.29303/jpft.v6i1.1827

\begin{abstract}
The teacher as an important figure in learning to encourage students to achieve high learning outcomes. In carrying out their activities, teachers who are members of the Physics Consultative Association (MGMP) of Physics in Pangkep Regency need to be evaluated. This research aims to plan the preparation, implementation and results of the Physics MGMP program in Pangkep Regency. To achieve these objectives, evaluative research has been conducted using the Countenance Stake's model. The subject of this research was the High School Physics Teacher Study Program (MGMP) in Pangkep Regency. Data collection uses interviews, observation, and documentation. Data were analyzed using the qualitative model of Miles and Huberman. Data analysis consists of three activities: data condensation, data display and conclusions. The results of data analysis that prove the evaluation of preparation is in accordance with the guidelines used. Implementation evaluation is in accordance with the guidelines used, but it needs to be on several aspects. Program evaluation of MGMP results depends on either category. Based on the evaluation findings of this program, it can be recommended that the MGMP program in Pangkep Regency can be continued with several improvements. So that the preparation is more optimal. While on the implementation schedule, active participants need to be optimized, and need an agenda related to the needs of teachers in the field.
\end{abstract}

Keywords: Evaluation; Programs; MGMP; Physics; models; Countenance Stake

\section{PENDAHULUAN}

Mutu pendidikan, selalu dikaitkan dengan kualitas sumber daya manusia (SDM) suatu Negara. Kualitas sumber daya manusia tergantung dari daya saing dari SDM tersebut. Seperti yang diungkapkan oleh Ketua Dewan Pertimb angan Presiden (Wantipres) Indonesia Adiningsih (2017), bahwa daya saing SDM Indonesia masih kalah dibandingkan negara tetangga, $50 \%$ pekerja di Indonesia hanya lulusan SD dan $90 \%$ pekerja tidak pernah ikut pelatihan.

Rendahnya daya saing SDM Indonesia disebabkan oleh kualitas pendidikan secara umum. Negara tetangga terdekat Indonesia seperti Malaysia dan Singupura, memiliki perolehan hasil belajar di bidang sains dan matematika lebih tinggi dibandingkan dengan siswa-siswa di Indonesia. Hal ini menunjukkan bahwa siswa-siswa Indonesia masih kalah bersaing dengan siswa negara lain. Hal ini terlihat dari beberapa indikator berskala internasional, antara lain melalui TIMSS dan PISA.

Siswa usia 15 tahun Indonesia masih menunjukkan prestasi yang kurang menggembirakan. Tahun 2018 pada bidang sains, Indonesia menempati rangking ke-70 dari 78 negara yang berpartisipasi dalam PISA. Peringkat ini mengalami perbaikan posisi dari urutan ke-38 dari 41 negara yang berpartisipasi pada tahun 2000 untuk bidang yang sama (Pratiwi, 2019).

Berdasarkan kenyataan di atas, maka hal ini menjadi tantangan tersendiri bagi guru matematika dan sains atau IPA di Indonesia. Sains memiliki tiga tahapan dalam pembelajarannya yakni observasi, klarifikasi, dan eksperimen (Sund \& Trowbridge, 1973). Beradasarkan kepada filosofi tersebut, maka sains tidak hanya merupakan sekumpulan pengetahuan yang 
berupa fakta, konsep atau prinsip saja, tetapi juga merupakan suatu proses penemuan. Itulah sebabnya sains Fisika dikembangkan berdasarkan teori-deduktif (Wisudawati \& Sulistyowati, 2014). Menurut Koballa \& Chiapetta (2010) hakikat Sains dapat dikelompokkan menjadi 4, yaitu, sains sebagai proses, sains sebagai sikap, sains sebagai produk, dan penerapan sains dalam teknologi.

Data PISA tahun 2018 menunjukkan betapa Indonesia masih mengalami permasalahan dalam bidang literasi, matematika, dan sains. Penyebab rendahnya hasil belajar siswa pada bidang tersebut, diduga disebabkan oleh sebaran guru yang belum merata, baik dari segi kuantitas maupun kualitasnya. Sebaran guru yang belum merata ini, dirasakan oleh Pemerintah Kabupaten (Pemkab) Pangkajene dan Kepulauan (Pangkep) Sulawesi Selatan. Pulau terluar Kabupaten Pangkep bahkan ada berbatasan dengan wilayah Provinsi Nusa Tenggara Barat dan Bali. Sebaran wilayah kepulauan inilah menjadi salah satu penyebab tidak meratanya hasil belajar siswa di Kabupaen Pangkep. Berdasarkan data Dinas Pendidikan Kabupaten Pangkep, diketahui bahwa Pangkep memiliki 15 buah MA negeri dan swasta, 18 SMA negeri dan swasta, dan 8 SMK negeri dan swasta.

Selanjutnya berdasarkan data pokok pendidikan (Dapodik) dasar dan menengah Kementerian Pendidikan dan Kebudayaan tahun 2020, diketahui jumlah guru SMA di Sulawesi Selatan sebanyak 9.567 orang (Dapodik, 2020). Jumlah guru yang demikian banyak ini tidak memungkinkan seluruhnya dapat mengikuti kegiatan peningkatan profesionalisme di Lembaga Penjaminan Mutu Pendidikan (LPMP), atau pada Pusat Pengembangan dan Pemberdayaan Pendidik dan Tenaga Kependidikan (P4TK) dalam waktu singkat. Kegiatan peningkatan profesionalisme guru hanya mungkin dilakukan melalui kegiatan musyawarah guru mata pelajaran (MGMP).

Istilah MGMP merupakan wadah asosiasi atau perkumpulan bagi guru mata pelajaran yang berada di suatu kabupaten/ kota yang berfungsi sebagai sarana untuk saling berkomunikasi, belajar, dan bertukar pikiran dan pengalaman dalam rangka meningkatkan kinerja guru sebagai praktisi pembelajaran di kelas (Sutrisno, 2014). Kinerja guru ini dapat terus ditingkatkan melalui beberapa kegitan MGMP dan pada akhirnya dapat meningkatkan profesionalisme guru, termasuk guru fisika.

Organisasi MGMP ini bersifat mandiri dan terbuka bagi semua guru mata pelajaran sejenis baik yang berstatus pegawai negeri sipil maupun guru tidak tetap, baik guru pada sekolah negeri maupun guru pada sekolah swasta. Pertemuan MGMP dilaksanakan secara periodik sesuai dengan jadwal sehingga memungkinkan peserta dapat terlibat tanpa mengganggu aktifitas pembelajaran di kelas. Pertemuan ini dilaksanakan sekurang-kurangnya 12 kali dalam satu tahun. (Depdiknas. 2009). Salah satu keunggulan MGMP yaitu dapat mempertemukan guru pelajaran sejenis dalam jumlah yang besar pada satu kegiatan. Kegiatannya dapat berupa penelitian, penulisan karya ilmiah, seminar, penerbitan jurnal dan berbagai kegiatan lainnya.

Program MGMP merupakan jaringan komunikasi profesi guru mata pelajaran dalam mengembangkan profesinya. Guru secara bersama-sama dapat melakukan penyusunan program tahunan, program semester, analisis materi pelajaran, program satuan pengajaran, metode pembelajaran, alat evaluasi, bahan ajar, pemanfaatan media pengajaran dan lain-lain (Hasyim, 2015). Kegiatan MGMP meliputi pemahaman dan penguasaan guru tentang kurikulum, perangkat pembelajaran, bahan ajar, metode 
pembelajaran efektif, sarana pembelajaran berbasis IPTEK dan media pembelajaran yang baik (Mahmud, 2015).

Dengan karakteristiknya yang demikian, maka MGMP sangatlah penting untuk dievaluasi. Evaluasi merupakan kegiatan pengambilan keputusan berdasarkan hasil penilaian melalui pengukuran dari kriteria program yang bersangkutan. Evaluasi adalah suatu proses merencanakan untuk memperoleh dan mengolah informasi yang diperlukan untuk membuat keputusan (Sani et al. 2020). Pengukuran dan evaluasi merupakan dua kegiatan yang berkesinambungan. Evaluasi dilakukan setelah dilakukan pengukuran dan keputusan evaluasi dilakukan berdasarkan hasil pengukuran. Pengambilan keputusan dilakukan dengan membandingkan hasil pengukuran dengan kriteria yang ditetapkan.

Dengan demikian, ada dua kegiatan dalam melakukan evaluasi yaitu melakukan pengukuran dan membuat keputusan. Keputusan dibuat dengan membandingkan hasil pengukuran dan kriteria evaluasinya. Evaluasi menjadi umpan balik untuk program yang telah dijalankan dan memberikan informasi yang diperlukan untuk menjalankan program di masa yang akan datang (Purwanto, 2012). Tyler (1950) mendefinisikan evaluasi program sebagai proses untuk mengetahui apakah tujuan pendidikan sudah dapat tereleasasikan. Sedangkan menurut Stufflebeam (2007) mengemukakan bahwa evaluasi program adalah upaya menyediakan informasi untuk disampaikan kepada pengambil keputusan.

Untuk mengevaluasi program MGMP diperlukan sebuah model evaluasi program. Model evaluasi program MGMP yang dipilih adalah model evaluasi Countenance dari Stake. Model evaluasi Countenance Stake dikenal juga dengan model evaluasi judgements (Sani et al. 2020). Stake mengatakan bahwa ada tiga tahapan dalam evaluasi program, yaitu antecedents, transaction, dan outcomes. Anteseden diartikan sebagai konteks, transaction diartikan sebagai proses, dan outcomes yang diartikan sebagai hasil. Model Stake menekankan kepada pelaksanaan dua hal pokok, yaitu description dan judgments. Kedua matriks yang digambarkan sebagai deskripsi dan pertimbangan, menunjukkan langkah-langkah yang terjadi selama proses evaluasi.

\section{METODE PENELITIAN}

Penelitian ini merupakan penelitian evaluatif yang menggunakan Model evaluasi Countenance Stake (Sani et al. 2020). Metode pengambilan subjek bersifat kualitatif. Subjek penelitian ini adalah pengurus MGMP Fisika, dan anggota MGMP Fisika Kabupaten Pangkep Sulawesi Selatan periode 2017-2019. Teknik pengumpulan data menggunakan pedoman wawancara, observasi dan dokumentasi. Ketiga jenis data yang diperoleh, lalu diuji keabsahan datanya menggunakan teknik triangulasi sumber dan metode.

Tabel 1. Teknik, Instrumen dan Sumber Data Evaluasi

\begin{tabular}{|c|c|c|c|}
\hline Komponen & Dimensi & Instrumen & $\begin{array}{c}\text { Sumber } \\
\text { Data }\end{array}$ \\
\hline \multirow[t]{5}{*}{ Antecedent } & $\begin{array}{l}\text { Organisasi } \\
\text { MGMP }\end{array}$ & $\begin{array}{ll}- & \mathrm{PW} \\
\text { - } & \mathrm{PO}\end{array}$ & - $\mathrm{PM}$ \\
\hline & $\begin{array}{l}\text { Perencana } \\
\text { an } \\
\text { Program } \\
\text { MGMP }\end{array}$ & $\begin{array}{ll}\text { - } & \mathrm{PW} \\
\text { - } & \mathrm{PO}\end{array}$ & - $\mathrm{PM}$ \\
\hline & $\begin{array}{l}\text { Sarana dan } \\
\text { Prasarana }\end{array}$ & $\begin{array}{ll}\text { - } & \text { PW } \\
\text { - } & \text { DO }\end{array}$ & $\begin{array}{ll}\text { - } & \mathrm{PM} \\
\text { - } & \mathrm{PS}\end{array}$ \\
\hline & SDM & $\begin{array}{ll} & \mathrm{PW} \\
\text { - } & \mathrm{PO}\end{array}$ & - $\mathrm{PM}$ \\
\hline & $\begin{array}{l}\text { Dana } \\
\text { Pelaksanaa } \\
\text { n Program } \\
\text { MGMP }\end{array}$ & $\begin{array}{ll}\text { - } & \mathrm{PW} \\
\text { - } & \mathrm{PO}\end{array}$ & - $\mathrm{PM}$ \\
\hline
\end{tabular}




\begin{tabular}{|c|c|c|c|}
\hline Komponen & Dimensi & Instrumen & $\begin{array}{c}\text { Sumber } \\
\text { Data }\end{array}$ \\
\hline Transaction & $\begin{array}{l}\text { Pelaksanaa } \\
\text { n Program } \\
\text { MGMP }\end{array}$ & $\begin{array}{ll}\text { - } & \text { PW } \\
\text { - } & \mathrm{PO} \\
\text { - } & \mathrm{DO}\end{array}$ & $\begin{array}{ll}\text { - } & \mathrm{PM} \\
\text { - } & \mathrm{PS}\end{array}$ \\
\hline Outcome & $\begin{array}{l}\text { Hasil } \\
\text { Program } \\
\text { MGMP }\end{array}$ & $\begin{array}{ll}\text { - } & \mathrm{PW} \\
\text { - } & \mathrm{DO}\end{array}$ & $\begin{array}{l}\text { - } \mathrm{PM} \\
\text { - } \mathrm{TS}\end{array}$ \\
\hline
\end{tabular}

Keterangan:

$\mathrm{PW}=$ Pedoman wawancara, $\mathrm{PO}=$ Pedoman observasi

DO = Dokumentasi, $\mathrm{PM}=$ Pengurus MGMP

PS = Peserta MGMP, TS = Teman sejawat

Data hasil yang telah diperoleh dianalisis menggunakan analisis data kualitatif Miles \& Huberman (1992) yang terdiri dari tiga kegiatan yaitu kondensasi data, displai data dan penarikan kesimpulan. Selanjutnya kriteria evaluasi program MGMP Fisika di Kabupaten Pangkep, terdiri atas tahap Antecedents, Transactions, dan Outcomes.

Tahap Antecedents, terdapat lima indikator evaluasi yang meliputi: organisasi MGMP, perencanaan program MGMP serta saranan dan prasarana, sumber daya manusia dan dana pelaksanaan program MGMP.

Tahap Transactions, terdiri atas satu indikator evaluasi meliputi pelaksanaan program. Pelaksanaan Program MGMP dikatakan berhasil berdasar kepada rencana kerja tahunan dan disesuaikan dengan kebutuhan dan memperhitungkan sumber pendanaan yang dimiliki oleh MGMP.

Tahap Outcomes, terdiri atas satu indikator evaluasi meliputi hasil pelaksanaan Program MGMP. Hasil pelaksanaan Program MGMP dikatakan berhasil jika meningkatnya pengetahuan, keterampilan, sikap, dan kinerja anggota MGMP dalam melaksanakan proses pembelajaran yang lebih profesional ditunjukkan dengan perubahan perilaku mengajar yang lebih baik di dalam kelas.

\section{HASIL DAN PEMBAHASAN}

Hasil penelitian akan disajikan berturut-turut mengenai tahap antecedent, transactions, dan outcomes. Adapun hasil penelitiannya diuraikan seperti berikut ini.

\section{Tahap Antecedents}

Komponen pertama pada tahap antecedent tentang persiapan program MGMP Fisika di Kabupaten Pangkep adalah tentang pembentukan pengurus MGMP. Data pembentukan pengurus MGMP, didapatkan melalui wawancara dengan Ketua MGMP Fisika, seperti berikut.
"Pembentukan Pengurus MGMP Fisika Kabupaten Pangkep dilaksanakan secara musyawarah mufakat oleh semua guru fisika SMA di Kabupaten Pangkep. Kemudian pembentukan struktur pengurus mengacu kepada anggaran dasar dan anggaran rumah tangga MGMP. Lalu setelah itu dikeluarkan surat keputusan (SK) dari Dinas pendidikan sebagai bukti legalitas pengurus MGMP Fisika Kabupaten Pangkep."

\section{Selanjutnya Sekretaris MGMP Fisika} ketika ditanya mengenai pembentukan pengurus MGMP mengatakan bahwa kami bersepakat dan menyetujui menunjuk ketua. Lalu ketua yang menunjuk perangkatperangkatnya atas persetujuan kami semua. Sekretaris MGMP ini merupakan guru fisika di SMAN 1 Bungoro Kabupaten Pangkep. Berikut petikan wawancaranya.
"Pembentukan pengurus MGMP itu sudah sesuai dengan pedoman MGMP yang kami dapatkan. Pengurus MGMP itu terdiri atas Ketua, Wakil ketua, Sekretaris, Wakil sekretaris dan Bendahara. Jadi pengurus inti MGMP berjumlah lima orang. Selain itu pembentukan pengurus MGMP sendiri dilakukan secara musyawarah dan mufakat oleh seluruh guru fisika di Kabupaten Pangkep. Kemudian setelah itu Dinas pendidikan menerbitkan SK pengurus MGMP Fisika Kabupaten Pangkep sebagai bukti legalitas." 
Dari penyataan tersebut di atas maka dapat disimpulkan bahwa untuk komponen Organisasi MGMP dari segi pembentukan kepengurusan telah sesuai dengan persyaratan pembentukan MGMP. Demikian juga struktur pengurus MGMP Fisika Kabupaten Pangkep dan bukti legalitas telah sesuai dengan pedoman pembentukan pengurus MGMP.

Komponen kedua pada tahap antecedent, yaitu komponen perencanaan program MGMP dikatakan tercapai jika adanya program kerja yang dibuat. Program kerja MGMP dibuat dalam bentuk jangka panjang maupun jangka pendek. Berikut hasil wawancara dengan Ketua MGMP Fisika Kabupaten Pangkep.

"Untuk perencaaan program, kami bagi menjadi dua yaitu jangka panjang dan jangka pendek. Pada dasarnya program jangka pendek itu biasanya dilaksanakan sesuai dengan kebutuhan dari anggota MGMP yang sifatnya mendesak. Sedangkan program jangka panjang, kami buat dalam jangka waktu setahun. Program kami susun tetap merujuk kepada program pemerintah pusat. Selebihnya program yang menjadi kebutuhan anggota."

Pendapat ketua MGMP Fisika Kabupaten Pangkep ini dilengkapi oleh Sekretaris MGMP seperti berikut.

\begin{abstract}
"Program kerja jangka pendek kami memasukkannya ke dalam program yang berasal dari block grant atau bantuan dari pemerintah pusat. Program ini kami laksanakan berdasarkan Petunjuk teknis (juknis) yang ada. Program jangka panjang kami laksanakan adalah program yang berasal dari pusat di luar dari pada program yang telah kami susun seperti program guru pembelajar dan kurikulum 2013. Selain itu untuk perancangaan program kerja sendiri kami libatkan seluruh anggota MGMP Fisika."
\end{abstract}

Berdasarkan penyataan tersebut di atas, dapat disimpulkan bahwa program kerja MGMP Fisika tidak ada pembagian program yang jelas mengenai pembagian program jangka panjang dan jangka pendek. Pembagian program tersebut hanya berdasarkan kepada bantuan yang diberikan oleh pemerintah pusat. Pembuatan program tidak ada perencanaan yang matang hanya muncul berdasarkan kebutuhan anggota secara mendesak.

Temuan di atas didukung oleh Onate \& Loekmono (2016) yang telah melakukan evaluasi program pada MGMP Bimbingan dan Konseling (BK) SMP/MTs Kota Salatiga. Evaluasi konteks menunjukkan bahwa dalam penentuan visi, misi dan tujuan program MGBK SMP/MTs Kota Salatiga tahun 2012 - 2015 berada dalam kategori kurang baik. Temuan ini bersesuaian dengan pendapat Yasri (2016) yang mengatakan bahwa Program MGMP pada dasarnya merupakan bagian utama dalam pengembangan MGMP. Program tersebut harus selalu merujuk pada usaha peningkatan kompetensi dan profesionalisme guru. Setiap program dan kegiatan MGMP diharapkan memiliki struktur program yang mencakup program umum dan program inti.

Pada komponen ketiga dari tahap antecedent yaitu komponen sarana dan prasarana. Komponen sarana dan prasarana dikatakan telah memenuhi, ketika saat kegiatan MGMP berlangsung didukung oleh sarana dan prasarana yang memadai. Berikut hasil wawancara dengan Ketua MGMP Fisika Kabupaten Pangkep.

\footnotetext{
"Aspek sarana dan prasarana pada dasarnya tidak ada kendala yang signifikan. LCD, papan tulis, dan laboratorium komputer semuanya tersedia. Pemilihan tempat pelaksanaan MGMP kami lakukan berdasarkan kesepakatan dari seluruh anggota MGMP. Kedepan, kami akan gilir dari satu sekolah ke sekolah lainnya sekaligus untuk bersilaturahmi dengan guru diberbagai sekolah. “
} 
Berdasarkan pada penuturan di atas maka dapat disimpulkan bahwa kelengkapan sarana dan prasarana sudah terpenuhi sesuai kriteria yang telah ditentukan. Selain itu pemilihan tempat pelaksanaan MGMP, telah sesuai dengan kriteria sebab menggunakan salah satua ruangan di SMAN 2 Pangkep. Sarana dan Prasarana di SMAN 2 Pangkep ini sangat lengkap dan nyaman untuk digunakan berbagai jenis kegiatan.

Temuan penelitian ini didukung oleh pendapat Suyanto dan Jihad (2013) yang mengatakan bahwa kegiatan MGMP dapat berlangsung dengan baik apabila mendapat dukungan internal dan eksternal. Dukungan internal adalah dari para guru itu sendiri sedangkan dukungan eksternal adalah dukungan sumber daya berupa sarana dan prasarana, tenaga, narasumber dan dana yang memadai.

Komponen keempat yaitu aspek sumber daya manusia. Dikatakan telah terpenuhi ketika narasumber dalam pelaksanaan kegiatan MGMP telah sesuai dengan pedoman pengangkatan narasumber. Berikut hasil wawancara dengan Ketua MGMP Fisika Kabupaten Pangkep seperti berikut.

"Narasumber yang akan kami undang bergantung pada agenda kegiatan yang kami laksanakan. Jika programnya tentang guru pembelajar yang merupakan program langsung dari kementerian, maka kami mengundang narasumber yang sesuai dengan kriteria dari kementerian. Jika program tersebut kami yang buat, maka persyaratannya cukup disesuaikan dengan pedoman seperti telah mengikuti Program Diklat TOT. Narasumber biasanya, dosen Universitas Negeri Makassar atau dari LPMP."

Hal di atas dipertegas oleh Bendahara MGMP Fisika Kabupaten Pangkep, yang mengatakan bahwa,

"Pemateri kami sesuaikan dengan agenda kegiatan dan biasanya dosen yang memiliki keahlian dalam agenda kegiatan yang kami laksanakan. Selain itu, biasanya kami mengundang pemateri dari LPMP Provinsi Sulawesi Selatan."

Berdasarkan data di atas maka dapat disimpulkan bahwa Narasumber yang menjadi pemateri dalam setiap kegiatan MGMP telah mengacu pada pedoman yang kementerian. Pemateri umumnya berasal dari unsur pengawas, dosen dan pemateri yang berasal dari LPMP Provinsi Sulawesi Selatan. Temuan penelitian ini sejalan pendapat Yasri (2016), yaitu SDM untuk mendukung kegiatan MGMP terdiri dari narasumber utama dan narasumber pendukung. Untuk narasumber utama terdiri atas guru sebagai anggota dan Instruktur atau fasilitator. Untuk narasumber pendukung berasal dari kepala sekolah, pengawas dan tenaga struktural dari Dinas Pendidikan kabupaten ataupun provinsi dan tenaga struktural dari instansi lain yang memenuhi syarat sebagai narasumber. Temuan ini didukung oleh temuan Onate \& Loekmono (2016) yang menyatakan bahwa selain sumber daya manusia, terdapat sumber dana dan sarana prasarana untuk mendukung pelaksanaan program MGMPBK.

Komponen kelima dari aspek persiapan, yaitu komponen dana pelaksanaan Program MGMP Fisika. Dikatakan berhasil jika memiliki pedoman yang mengatur berbagai aspek pengelolaan secara tertulis dalam bentuk pertanggungjawaban pengelolaan dana. Data hasil wawancara dengan Ketua MGMP Fisika Kabupaten Pangkep seperti berikut.

"Sumber dana kami memiliki tiga sumber utama yaitu sumber dana dari APBD Kabupaten Pangkep. Kedua berasal dari Pemerintah Pusat berupa Block grant dan sumber dana mandiri dari uang iuran anggota MGMP Fisika. Penggunaan dari setiap dana yang turun disesuaikan dengan proposal yang kami 
ajukan. Demikian juga dana yang berasal dari APBD Pemda Pangkep. Semua Pertanggungjawaban penggunaan keuangan, kami masukkan ke dalam laporan pertanggungjawaban pengurus MGMP Fisika Kabupaten Pangkep."

Ungkapan Ketua MGMP Fisika dipertegas oleh Bendahara MGMP Fisika Kabupaten Pangkep, seperti berikut.

\begin{abstract}
"Sumber dana yang kami dapatkan itu berasal dari bantuan pemerintah pusat sesuai dengan proposal yang kami usulkan. Selain itu dari dana mandiri dari anggota MGMP Fisika. Untuk pengelolaan dana, sebagai bendahara saya hanya menerima laporan penggunaan keuangan dari ketua dan sekretaris MGMP Fisika. Setelah itu kemudian keseluruhan penggunaan dana dilaporakan dalam bentuk laporan pertanggung jawaban pengurus MGMP Fisika."
\end{abstract}

Berdasarkan pada pernyataan di atas maka dapat disimpulkan bahwa sumber dana MGMP Fisika Kabupaten Pangkep berasal dari tiga sumber. Ada sumber dana dari APBD Pemda Pangkep, Kementrian Pendidikan dalam bentuk Blockgrant, dan ketiga berasal dari sumber dana mandiri anggota MGMP Fisika Kabupaten Pangkep. Untuk pengelolaan dana disesuaikan dengan kebutuhan masing-masing kegiatan sesuai dengan proposal yang diajukan. Pertanggungjawaban penggunaan dana dilaporkan dalam bentuk laporan pertanggungjawaban pengurus MGMP Fisika Kabupaten Pangkep.

Selain pengurus MGMP sebagai sumber data, juga data diperoleh dari anggota MGMP Fisika Kabupaten Pangkep. Hasil wawancara dirangkum seperti ungkapan di bawah ini.

"Pada dasarnya sarana dan prasarana MGMP sangat baik, seperti sarana laboratorium yang lengkap. Tempat pelaksanaan MGMP dapat kami jangkau dan setiap peserta diberi biaya transportasi."
Berdasarkan data di atas, dapat disimpulkan bahwa pada aspek persiapan sarana dan prasarana telah terpenuhi. Kebutuhan seluruh anggota MGMP Fisika Kabupaten Pangkep telah terpenuhi. Selain itu, akses menuju lokasi kegiatan juga mudah dijangkau oleh para anggota MGMP. Dengan demikian, secara keseluruhan aspek persiapan MGMP Fisika telah disiapkan segalanya. Artinya komponen evaluasi antecedent MGMP fisika Kabupaten Pangkep telah terpenuhi.

Berdasarkn hasil observasi yang telah dilakukan, diperoleh data bahwa papan struktur pengurus MGMP tidak ditemukan. Walau demikian, SK pengurus MGMP Fisika Kabupaten Pangkep ditemukan ada dan ditandantangani langsung oleh Kepala Dinas Pendidikan Kabupaten Pangkep. Hal ini menunjukan bahwa organisasi MGMP fisika Kabupaten Pangkep telah memiliki Pengurus yang syah dan legal.

Hasil observasi langsung pada aspek perencanaan program MGMP fisika Kabupaten Pangkep diperoleh data bahwa kelengkapan buku program jangka pendek dan jangka panjang ada. Bentuknya memang dalam softcopy, bukan hardcopy. Demikian juga untuk aspek sarana dan prasarana mengenai kelengkapan buku adminstrasi, buku keuangan dan kelengkapan sarana pada saat kegiatan untuk buku adminstrasi dan keuangan semua dalam bentuk hardcopy. Hal ini dapat difahami bahwa sekarang ini memang tidak terlalu penting yang namanya hardcopy asal ada softcopynya.

Untuk aspek SDM tentang pedoman kriteria narasumber, berdasar pada pedoman yang diberikan dari pusat dalam bentuk softfile, telah terpenuhi. Aspek dana pelaksanaan program dalam bentuk buku laporan keuangan, ada ditemukan tetapi semua dalam bentuk softfile yang telah dibuat dalam format $p d f$. Demikian juga untuk laporan pertanggungjawaban pengurus MGMP Fisika Kabupaten Pangkep juga ada dalam format $p d f$. Hal ini 
membuktikan bahwa MGMP fisika di Kabupaten Pangkep telah terencana dengan baik.

\section{Tahap Transactions}

Komponen transactions atau pelaksanaan program MGMP Fisika Kabupaten Pangkep dikatakan berhasil apabila rencana kerja tahunan disesuaikan dengan kebutuhan dan disesuaikan dengan sumber pendanaan yang dimiliki oleh MGMP. Berdasarkan hal tersebut, berikut disajikan data wawancara langsung dengan ketua MGMP Fisika Kabupaten Pangkep seperti berikut.

\begin{abstract}
"Sebelum pelaksanaan kegiatan, pada bagian awal kami jelaskan kepada seluruh anggota mengenai pedoman kegiatan MGMP. Program kerja apa saja yang akan dilaksanakan dan sampai kapan pelaksanaannya. Selain itu, dana yang kami peroleh dari berbagai sumber kami sesuaikan dengan agenda kegiatan. Keluhan dari anggota hanya ada pada persoalan waktu pertemuan yang sulit. Tingkat partisipasi dari seluruh anggota hanya mencapai $80 \%$."
\end{abstract}

Berdasarkan data di atas maka dapat disimpulkan bahwa pelaksanaan kegiatan MGMP Fisika telah sesuai dengan pedoman. Aspek pelaksanaan besaran kegiatan disesuaikan dengan anggaran yang diterima dan anggaran yang diajukan pada proposal. Setiap agenda pelaksanaan kegiatan ada penjelasan awal yang dilakukan. Kemudian untuk keluhan anggota hanya pada persoalan waktu pertemuan saja.

Selanjutnya berdasarkan wawancara dengan guru fisika SMAN 1 Labakkang, diperoleh data seperti berikut.

\footnotetext{
"Setiap pelaksanaan kegiatan yang kami lakukan itu selalu ada pedoman dan pedoman itu dijelaskan oleh Ketua. Selain itu seluruh agenda kegiatan telah terlaksana. Program yang dibuat oleh pengurus telah sesuai dengan kebutuhan di lapangan."
}

Senada dengan ungkapan tersebut, guru fisika SMAN 1 Pangkep juga mengatakan demikian. Berdasarkan data di atas maka dapat disimpulkan bahwa pelaksanaan kegiatan MGMP telah sesuai dengan pedoman yang ada. Penyesuaian program dengan kebutuhan di lapangan terus dilakukan oleh pengurus MGMP. Dengan demikian komponen transaction telah terlaksana dengan baik.

Berdasarkan hasil observasi langsung yang telah dilakukan pada aspek pelaksanaan MGMP Fisika Kabupaten Pangkep ditemukan bahwa buku pedoman kegiatan tidak ada ditemukan dalam bentuk hardcopy. Yang ada hanya penyampaian dari pengurus MGMP Fisika Kabupaten Pangkep. Selain itu untuk daftar hadir peserta ditemukan ada dalam bentuk hardcopy sebagai arsip. Kemudian untuk agenda dan daftar program semua ada dalam bentuk softfile dan tidak dibagikan ke peserta hanya diberikan penjelasan sebelum kegiatan dilaksanakan.

\section{Tahap Outcomes}

Komponen ketercapaian hasil pelaksana- an atau disebut tahap outcomes program MGMP Fisika dikatakan berhasil apabila terjadi peningkatan pada aspek pengetahuan, keterampilan, sikap, dan kinerja anggota MGMP. Hal ini ditunjukkan oleh perubahan perilaku mengajar yang lebih baik di dalam kelas oleh para anggota MGMP. Berdasarkan wawancara dengan guru fisika SMAN 1 Labakkang, diperoleh data seperti berikut.

\footnotetext{
"Setelah mengikuti MGMP maka ada banyak perubahan yang saya rasakan pada aspek adminstrasi dan keterampilan mengajar. Penerapan hasil MGMP kami sesuaikan dengan budaya dan kebiasaan di sekolah, seperti pengisian LKS, RPP dan sebagainya. Dulu pernah ada pelatihan karya tulis tetapi belum ada lagi kelanjutannya sekarang."
}

Berbeda sedikit dengan ungkapan tersebut, guru fisika SMAN 1 Pangkep 
mengungkapkannya melalui wawancara seperti berikut.

\begin{abstract}
"Jelasnya ada perubahan yang kami rasakan. Sebagai contoh, ketika kami bertemu para anggota MGMP biasanya saling share ilmu ataupun kendala yang kami hadapi di sekolah. Seperti penulisan karya tulis ilmiah dan peningkatan profesionalisme kami masing-masing. Kendala kami adalah beragamnya kebutuhan kami di lapangan. Sementara program kerja MGMP, belum mampu mewadahi semua kebutuhan anggota di lapangan. Saran kepada pemberi dana, sekali-kali turunlah ke lapangan untuk memetakan kebutuhan kami. Kiranya program kerja kami tetap mengakomodir keinginan pusat dan sinkron dengan apa yang kami butuhkan di lapangan."
\end{abstract}

Untuk mendapatkan data sebanyak mungkin mengenai komponen hasil pelaksanaan program MGMP, telah diwawancarai juga teman sejawat guru di SMAN 1 Labakkang dan SMAN 1 Segeri yang hasilnya seperti berikut.

"Saya berpandangan bahwa setelah teman guru fisika mengikuti MGMP Fisika, beliau banyak mengalami peningkatan kemajuan dalam hal pembelajaran di kelas. Selain itu dia juga banyak mengalami peningkatan dalam hal administrasi kelengkapan mengajar. Intinya dia banyak memotivasi siswa dalam mengajar dan beberapa kreasi positif lainnya. Salah satu contoh peningkatan proses mengajar bagi guruguru lain di sekolah kami, ada metode mengajar baru dishare kepada kami."

Untuk mengetahui bahwa guru fisika telah mengajar dengan baik dan menyenangkan serta senantiasa memotivasi siswa maka diadakan observasi kelas pada beberapa sekolah. Setelah mengamati cara guru mengajar dan antusiasme siswa dalam mengikuti pembelaran, maka dapat disimpulkan bahwa tahap outcomes ini telah sesuai dengan kriteria program yang telah ditetapkan. Kriteria program dikatakan berhasil apabila telah terjadi peningkatan pada aspek pengetahuan, keterampilan, sikap, dan kinerja anggota MGMP.

Berdasarkan kenyataan tersebut di atas maka dapat disimpulkan bahwa pelaksanaan program MGMP Fisika di Kabupaten Pangkep telah berhasil meningkatkan pengetahuan, keterampilan, sikap, dan kinerja anggota MGMP. Selain itu. Pelaksanaan program MGMP dapat memberikan efek positif terhadap peningkatan minat belajar siswa dan peningkatan mutu sekolah.

\section{PENUTUP}

Berdasarkan uraian sebelumnya bahwa profesionalisme guru fisika dapat dikembangkan melalui MGMP. Oleh karenanya, perlu diadakan evaluasi tentang program yang ada di MGMP. Sesuai dengan analisis data penelitian, maka dapat di simpulkan seperti berikut. Tahap antecedent, secara keseluruhan telah terencana sesuai dengan pedoman perencanaan program MGMP yang digunakan.

Tahap transactions telah terlaksana sesuai dengan pedoman yang digunakan namun pada beberapa aspek seperti keaktifan peserta yang masih perlu ditingkatkan. Perlu juga ada penyesuaian antara agenda yang dilaksanakan dengan kebutuhan guru di lapangan. Tahap outcomes telah menghasilkan peningkatan pada aspek pengetahuan, keterampilan, sikap, dan kinerja anggota MGMP. Konten materi yang diberikan kepada peserta MGMP hendaknya lebih fokus kepada hal yang dapat diimplementasikan langsung di kelas oleh peserta MGMP. Pada tahap antecedent perlu pembagian yang jelas antara program jangka pendek dan jangka panjang. Penyusunan program dapat lebih terarah ke dalam skala prioritas terutama program yang diberikan pemerintah pusat. 


\section{REFERENSI}

Adiningsih, S. (2017). Daya Saing SDM Indonesia, http://wantimpres.go.id/? $p=1509 \&$ lang $=i d$ (diakses 8 April 2020).

Data Pokok Pendidikan Dasar dan Menengah Direktorat Jenderal Pendidikan Anak Usia Dini, Pendidikan Dasar dan Pendidikan Menengah Kementerian Pendidikan dan Kebudayaan, https://dapo.dikdasmen.kemdikbud.g o.id/guru/1/190000, diakses pada tanggal 4 Mei 2020.

Depdiknas. (2009). Prosedur Operasional Standar Penyelenggaraan KKG $M G M P$. Direktorat Jenderal Peningkatan Mutu Pendidik dan Tenaga Kependidikan.

Hasyim, M. (2015). Efektifitas Musyawarah Guru Mata Pelajaran (MGMP) Guru Pendidikan Agama Islam, Jurnal Pusaka, 2(2): 30-43.

Koballa \& Chiapetta. (2010). Science Instruction in the Middle and Secondary Schools. Pearson: USA.

Mahmud, (2015). Ilmu Pendidikan. Bandung: Pustaka Setia.

Miles, M. B., \& Huberman, A. M., (1992). Analisis Data Kualitatif. Jakarta: Universitas Indonesia Press.

Onate, M. E., \& Loekmono, J. L. (2016). Evaluasi Program Musyawarah Guru Bimbingan dan Konseling SMP/MTS Kota Salatiga Tahun 2012-2015. Kelola: Jurnal Manajemen Pendidikan, 3(2), 294309.

Pratiwi, I. (2019). Efek Program Pisa Terhadap Kurikulum Di Indonesia. Jurnal pendidikan dan Kebudayaan, 4(1), 51-71.

Purwanto, N. (2012). Evaluasi Pengajaran. Bandung: PT. Remaja Rosdakarya.

Sani, R. A., Arafah, K., Aziz, I., Tanjung, R., \& Suswanto, H., (2020). Evaluasi Proses dan Penilaian Hasil Belajar,
Bandung: PT Remaja Rosdakarya. ISBN 978-602-446-430-1.

Stufflebeam, D. L., \& Sinkfield, A. J., (2007). Evaluatoin Theory, Models \& Applications. San Francisco: Jossey-Bass.

Sund, R. B., \& Trowbridge, L. A. W. (1973). Teaching Science by Inquiry in the Secondary School Second Edition. United State of America: Charles E. Merill Publishing Company A Bell \& Howell Company.

Sutrisno, B. (2014). MGMP: Inovasi Pendidikan, http://mgmpkwugunkid. blogspot.com/2014/01/manfaat-mgm p-bagi-guru.html, diakses tanggal 4 Mei 2020.

Suyanto \& Jihad, A., (2013). Menjadi guru profesional "Strategi Meningkatkan kualifikasi dan kualitas guru di era global". Jakarta: Erlangga

Tyler, R. W. (1950). Basic Principles Curriculum and Instruction, Syillabus for Education, Chicago: The University of Chicago Press

Undang-Undang Nomor 14 Tahun 2005 Tentang Guru dan Dosen. Jakarta : Kementrian Pendidikan Nasional

Wisudawati, A. W., \& Sulistyowati, E., (2014). Metodologi Pembelajaran IPA. Jakarta: Bumi Aksara.

Yasri, (2016). Konsep Pengembangan MGMP Bagi Widyaiswara. Jakarta : Badan Litbang dan Diklat Kementerian Agama. 